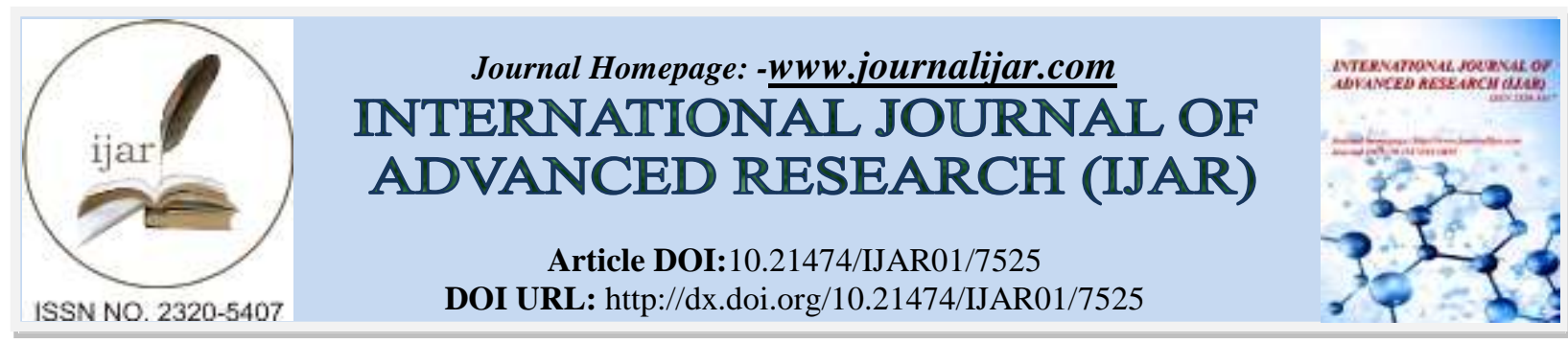

RESEARCH ARTICLE

\title{
USE OF MUCODERM® COLLAGEN MATRIX IN PERI-IMPLANT AESTHETIC DEFECT CORRECTION.
}

Ricardo Henrique Nunes Prando ${ }^{1}$, Rayra Batista Balestrassi ${ }^{1}$, Poliana Keller Andrade ${ }^{1}$, Jefferson David Melo de Matos ${ }^{2}$, Pedro Jacy Santos Diamantino ${ }^{2}$, John Eversong Lucena de Vasconcelos ${ }^{3}$, Guilherme da Rocha Scalzer Lopes ${ }^{4}$, Eduardo Cláudio Lopes de Chaves e Mello Dias ${ }^{5}$ and Fábio Matos Chiarelli ${ }^{6}$.

1. School of Dentistry, Faculdade São Francisco de Assis ESFA, Santa Teresa - ES, Brazil.

2. Post Graduate Student - Masters Degree Program, Department of Prosthodontics, Universidade Estadual Paulista Júlio de Mesquita Filho UNESP, São José dos Campos - SP, Brazil.

3. Professor of Oral Implantology, Department of Dentistry, Centro Caririense de Pós-Graduação CECAP, Juazeiro do Norte - CE, Brazil.

4. Post Graduate Student - Ph.D Program, Department of Prosthodontics, Universidade Estadual Paulista Júlio de Mesquita Filho UNESP, São José dos Campos - SP, Brazil.

5. Ph.D in Dentistry, Department of Implantology, Faculdade de Odontologia São Leopoldo Mandic SLMANDIC, Campinas - SP, Brazil.

6. Professor of Oral Implantology, Department of Dentistry, Faculdade São Francisco de Assis ESFA, Santa Teresa - ES, Brazil.

\section{Manuscript Info}

Manuscript History

Received: 10 June 2018

Final Accepted: 12 July 2018

Published: August 2018

Keywords:-

Tissue Regeneration, Periodontal;

Esthetics, Dental;Dental Implants.

\begin{abstract}
Introduction: Soft tissue defects around osseointegrated implants have stimulated the development of techniques aimed at reducing these defects, especially when located in areas of the premaxilla. Case Report: A 40-year-old, female, non-smoker, sought dental care complaining of darkening around the region where isan implant corresponding to element 12 . On clinical examination, it was observed that peri-implant mucosa was present thin with a depression revealing a shading in vestibular aesthetic area and a palatinized prosthesis on implant. Discussion: Allografts appeared in the market as a substitute for autogenous connective graft, with the proposal to avoid a second surgical area, besides shortening the procedure time and reducing postoperative discomfort. Conclusion: The use of Mucoderm ${ }^{\circledR}$ in aesthetic area provides excellent results, establishing and maintaining the facial bone wall; in addition, contributes to the formation of a thick soft tissue in the aesthetic area, besides providing a better postoperative and avoiding a second surgical site.
\end{abstract}

Copy Right, IJAR, 2018,. All rights reserved.

\section{Introduction:-}

Soft tissue defects around osseointegrated implants have stimulated the development of techniques aimed at reducing these defects, especially when located in areas of the premaxilla ${ }^{1}$.

Soft tissue reconstruction can be performed using techniques such as autogenous connective tissue graft and biomaterials grafts, especially Mucoderm ${ }^{\circledR}$ (Botiss Biomaterials - Straumann), which presents itself as a true 
alternative to connective tissue graft of the own patient ${ }^{2}$. This three-dimensional collagen matrix, originated from the dermis of animals is stable and used to replace soft tissue, contributing to rapid revascularization and tissue integration $^{3}$.

The hard palate is considered as gold standard with regard to the donor area of connective tissue, but its disadvantages arise from the requirement of two surgical sites, be it the donor or the recipient, which causes an increase in postoperative morbidity, pain, surgical time and difficulty in performing oral hygiene during the cicatricial period ${ }^{4}$.

The biomaterial Mucoderm ${ }^{\circledR}$ (Botiss Biomaterials - Straumann) is a collagen matrix of porcine origin that, after passing through processes that avoid potential rejection, allows the proliferation of fibroblasts, revascularization and integration of the graft after its allocation in the surgical bed ${ }^{5}$. In addition, it has excellent characteristics, such as: high tensile strength due to its structural stability, being able to be stabilized by sutures, pins, even screws; can easily be cut into several sizes and inserted into surgical beds by the tunneling technique without any obvious risks of tearing the matrix ${ }^{6}$. Its structure is similar to that of human tissue, making it a viable alternative to tissue grafting, with regard to the complete integration of the patient's own tissue within 6 to 9 months. In addition, have a capacity of reduction of patient discomfort and donor site morbidity ${ }^{7}$.

It is necessary to rehydrate the Mucoderm ${ }^{\circledR}$ matrix in sterile saline solution or blood for 5 to 20 minutes before application; the rehydration time depends on the technique applied and the flexibility desired for the matrix, being that the longer the rehydration time, the greater the flexibility of the graft ${ }^{8}$. After rehydration, the size and shape of the matrix can easily be adapted to the defect if it is rehydrated for a short time and, therefore, if the matrix is not so flexible, it can be cutted or rounded its edges to avoid the perforation of the gingival tissue during the closure of the flap ${ }^{9}$. For covering multiple recessions, the membrane may be elongated by cutting the matrix on alternate sides where the two ends are pulled to stretch it and the indication determines if the matrix should be covered or exposed; the exposure of the matrix should always be avoided in the treatment of recession defects, and it should be ensured that the repositioned flap completely covers the matrix ${ }^{10}$.

Full coverage ensures the growth of blood vessels and cells starting from the overlapped flap, and thus, the rapid incorporation of the graft ${ }^{11}$. Early exposure may lead to rapid absorption and contamination of the collagen matrix, causing graft failure of soft tissue ${ }^{12}$. Open healing is only possible if small parts of the matrix are exposed, and revascularization may occur from the adjacent margins of the flap. It is worth pointing out that this possibility still viable if thr membrane is fixed very close to the underlying periosteum ${ }^{13}$.

The present study aims to report a clinical case on the use of the Mucoderm ${ }^{\circledR}$ collagen matrix in perimplant aesthetic defect corrections.

\section{Case Report:-}

A 40-year-old, female, non-smoker, sought dental care complaining of darkening around the region where is an implant corresponding to element 12 . On clinical examination, it was observed that peri-implant mucosa was present thin with a depression revealing a shading in vestibular aesthetic area and a palatinized prosthesis on implant. (Fig 1 and 2). 


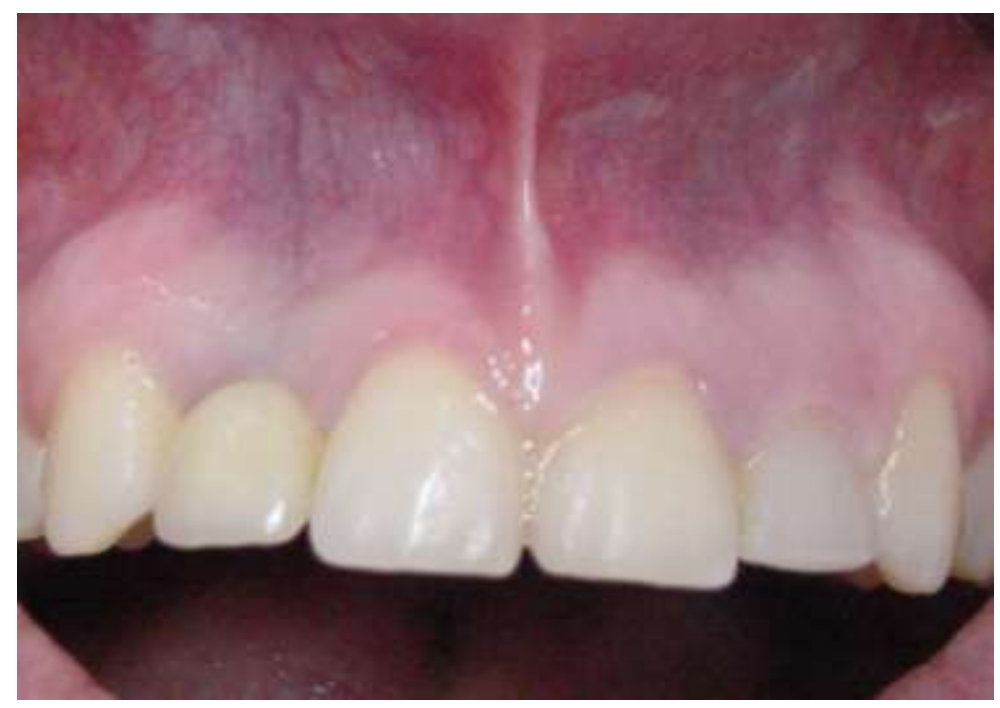

Figure.1:- Preoperative clinical examination in frontal view.

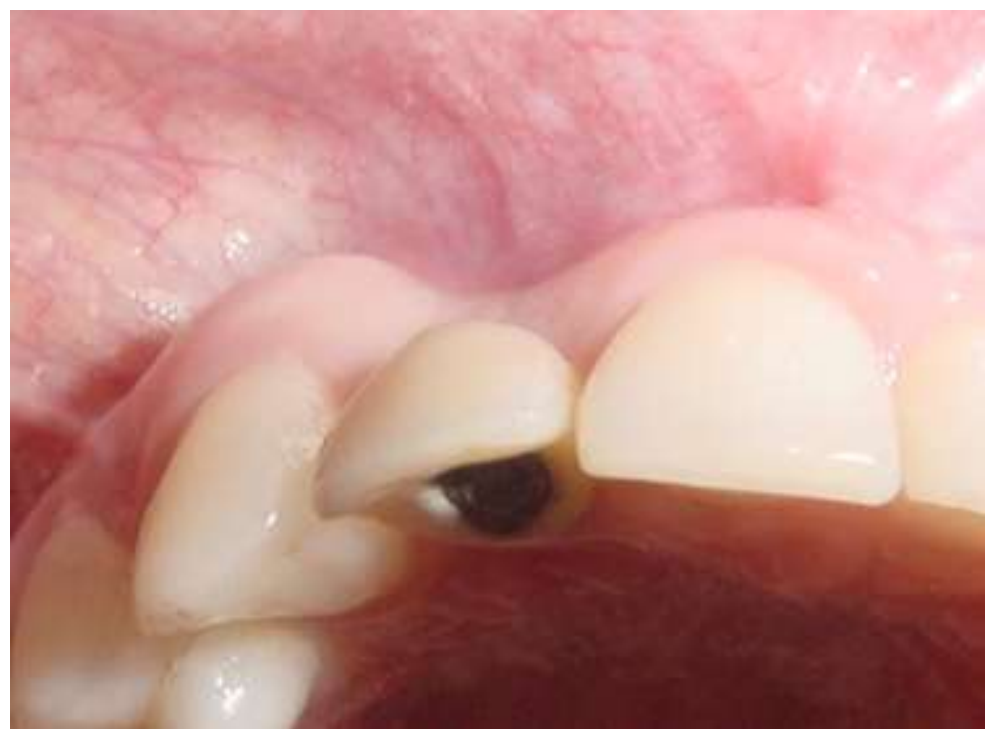

Figure. 2:- Occlusal view showing depression in area to be grafted.

In the planning, there was a need for graft surgery in the region where the depression was found, and asa less traumatic option was used a soft tissue substitute, called Mucoderm® (Botiss biomaterials, Straumann). The preoperative medication was Amoxicillin 500mg, two capsules, one hour before surgery. Intra-oral antisepsis was performed with chlorhexidine $0.12 \%$, and povidine $1 \%$ was used during the extra-oral antisepsis. After local anesthesia, a horizontal incision was made that extended from the distal of the element 13 to the distal of element 11. Later, the mucoperiosteal in the graft receiving region was detached (Fig. 3). 


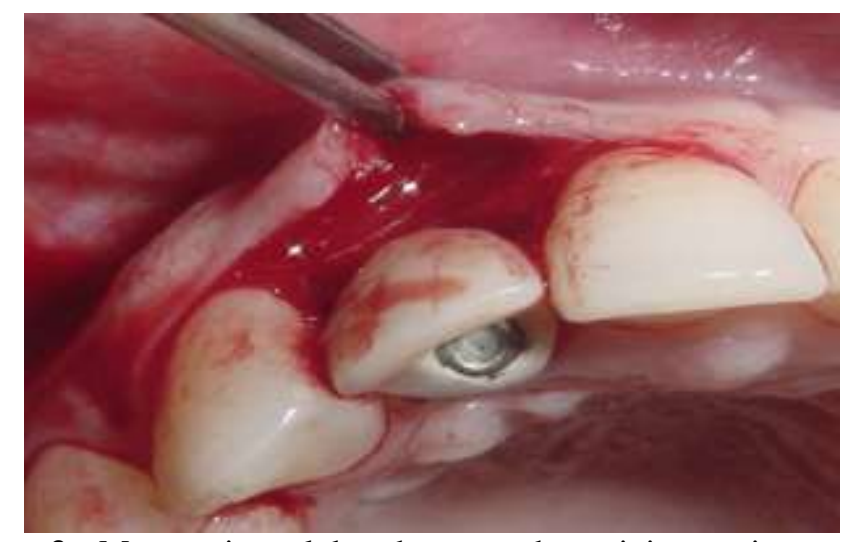

Figure. 3:- Mucoperiosteal detachment at the recipient region.

Then the Mucoderm ${ }^{\circledR}$ graft (Botiss Biomaterials, Straumann) was positioned and sutured in the recipient area, using monofilament yarns. The flap was repositioned and coronally sutured (Fig. 4 and 5).

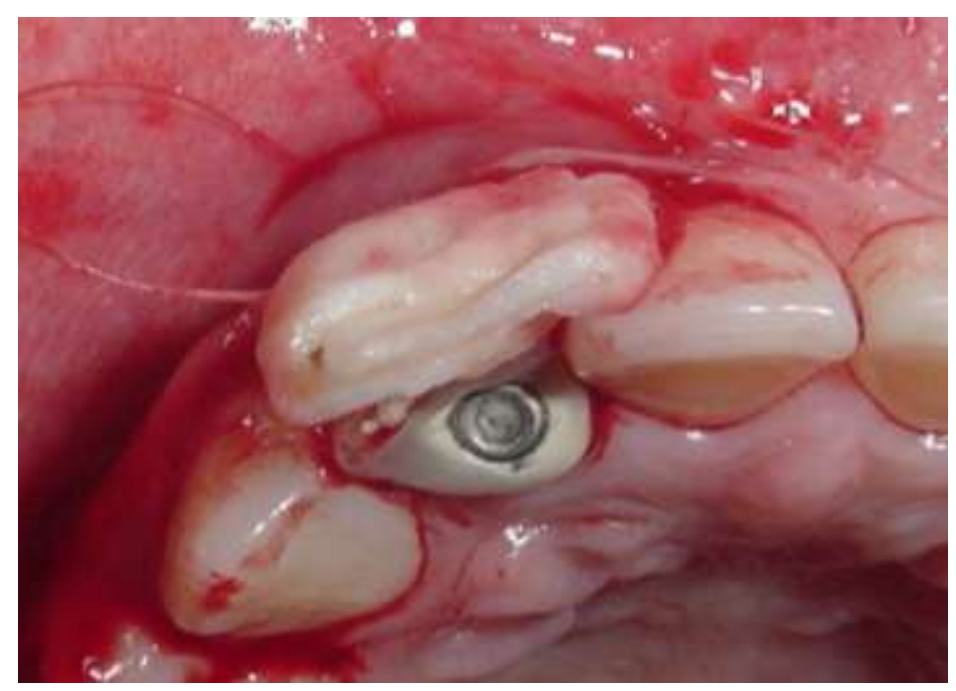

Figure. 4:- Sutured graft in recipient area.

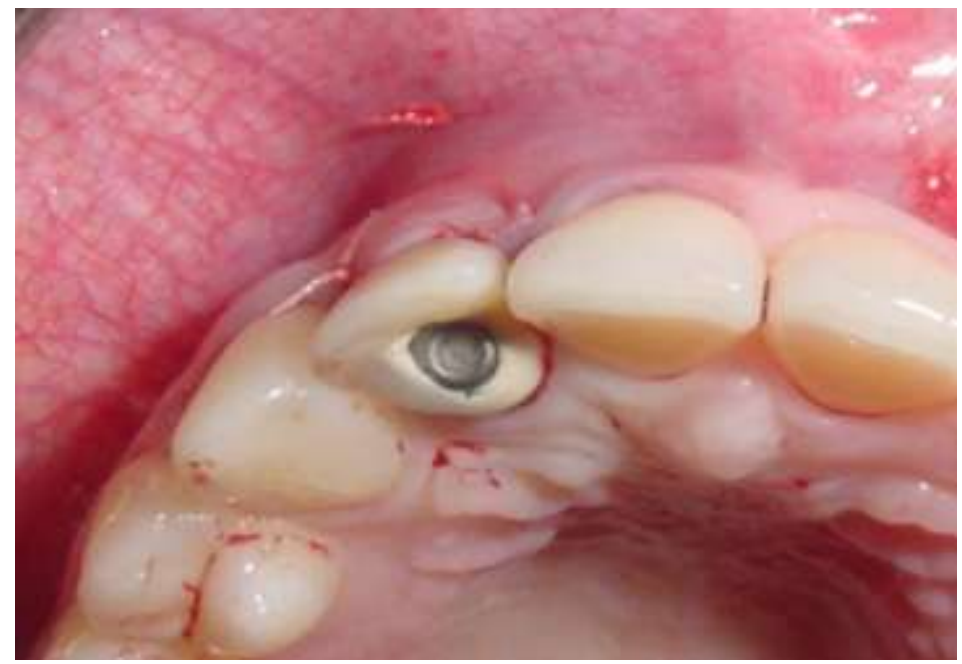

Figure. 5:-Clinical condition of the grafted region (immediate postoperative). 
In a 5-month postoperative clinical examination, a scar was observed in the grafted region and a significant decrease in the initial depression (Fig. 6 and 7).

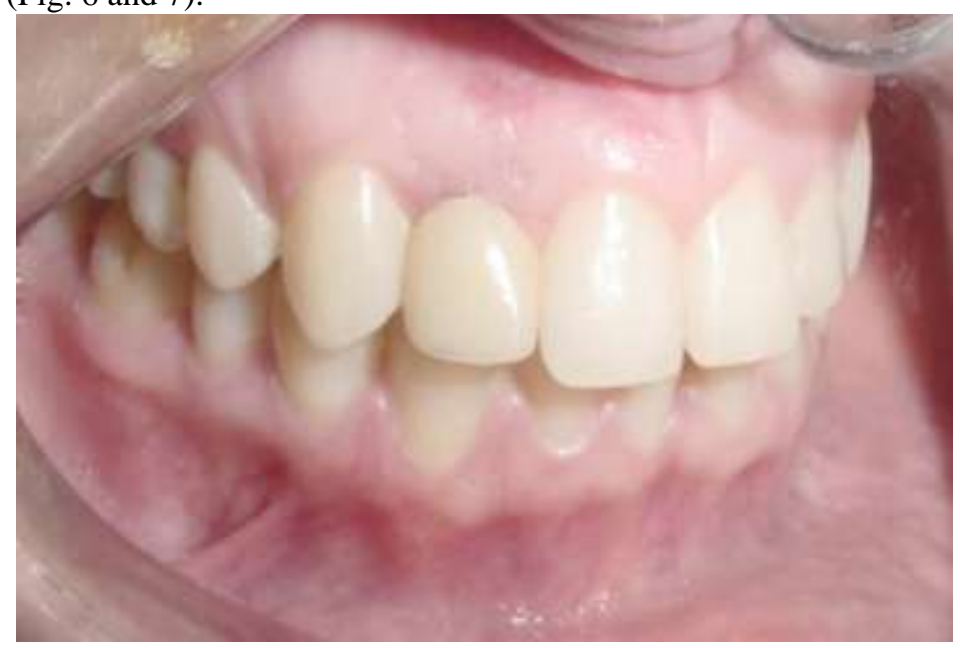

Figure. 6:-Vestibular view (five months postoperative).

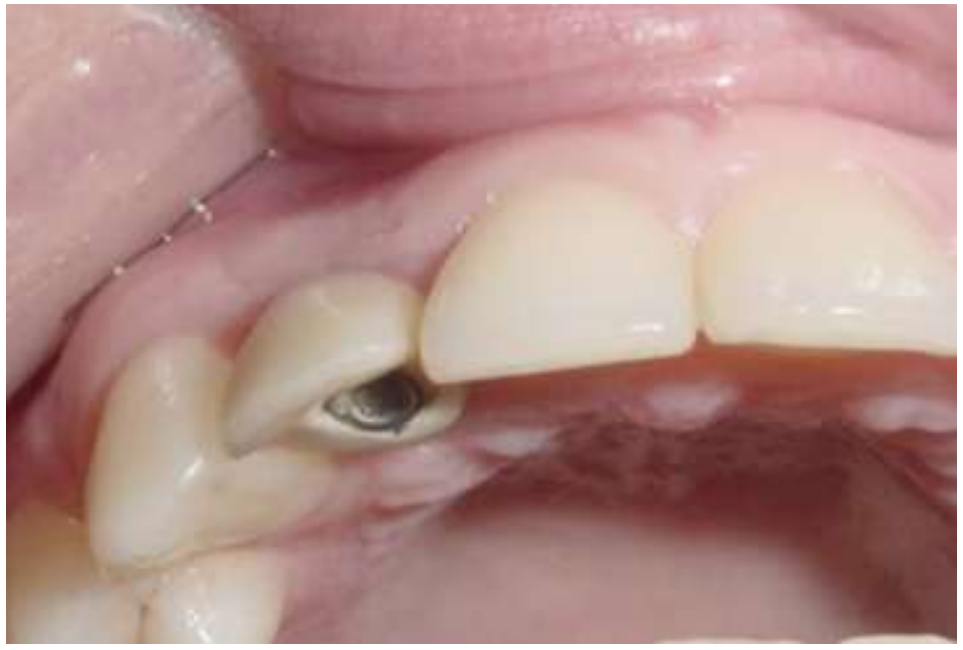

Figure. 7:- Occlusal view (five months postoperative).

After 10 months of the graft placement surgery, a new prosthetic abutment was made; we chose to use an aesthetic pillar because of the initial shading complaint and therefore the zirconia pillar was chosen. It is possible to observe that at the end of the case, soft tissue shading and depression were corrected and gingival aesthetic were reestablished, with remarkable gain of keratinized soft tissue in the vestibular region (Figs. 8, 9 and 10). 


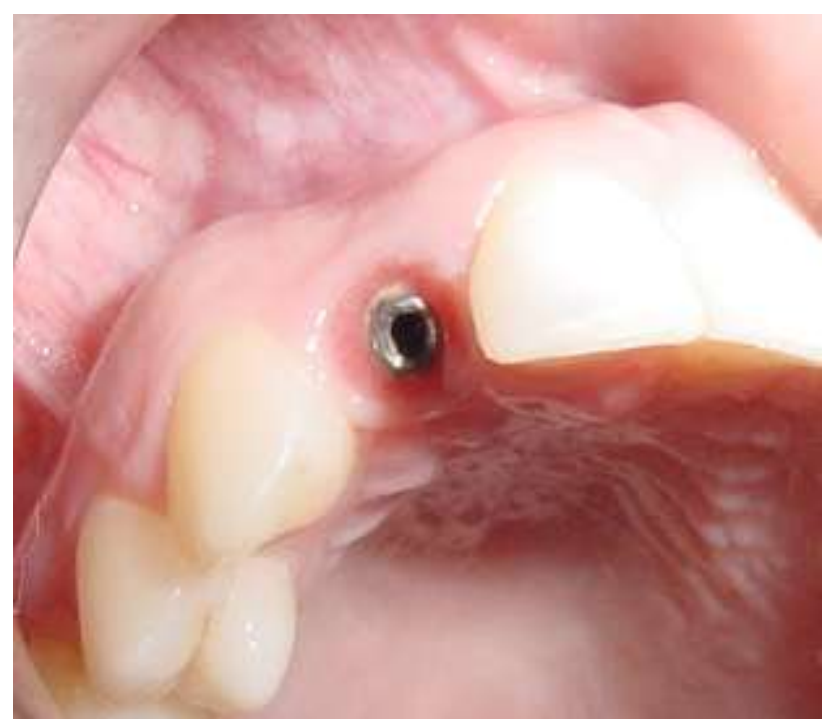

Figure. 8 :-Occlusal view (ten months postoperative).

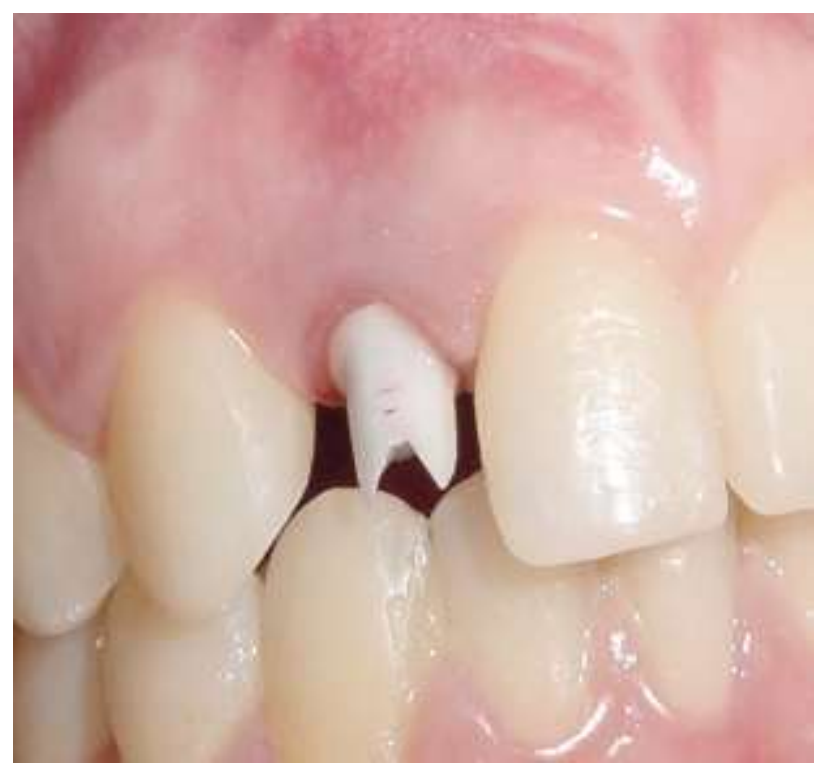

Figure. 9:- Zirconia abutment in vestibular view. 


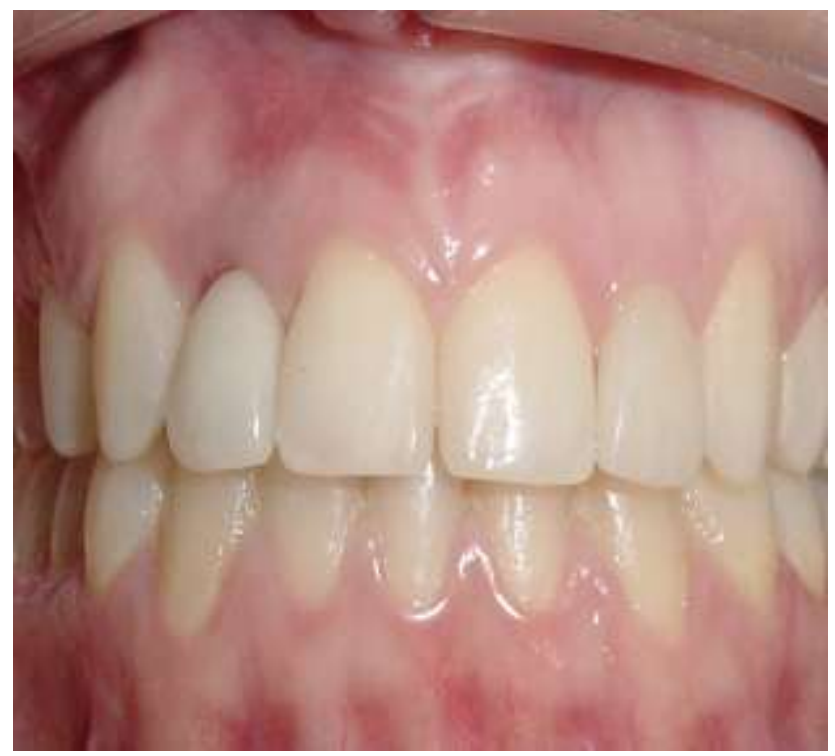

Figure. 10:-Final appearance of peri-implant tissue.

\section{Discussion:-}

For a long time, free gingival grafting techniques and connective tissue grafts were used with great success. However, it is not widely used, due to the fact that the technique requires a second surgical site, second intention healing, generate painful postoperative, limitation in multiple teeth in the same session - due to the limited supply of the donor tissue - and the aestheticquestion because it results in a patchy appearance ${ }^{14}$. According to Matos et al. (2017) the allografts appeared in the market as a substitute for autogenous connective graft, with the proposal to avoid a second surgical area, besides shortening the procedure time and reducing postoperative discomfort ${ }^{15}$.

According to Pereira et al. (2017) when a partial thickness flap is prepared, the collagen membrane should be sutured to the intact periosteum to ensure close contact between the matrix and the periosteal wound bed, and single or " $x$ " sutures may be used. However, the use of absorbable sutures is normaly recomended, allowing an intimate fixation of the surgical borders ${ }^{16}$.

After surgery, any mechanical trauma should be avoided at the treated site and patients should be instructed not to brush their teeth over the operated area until four weeks after surgery. The prevention of plaque can be done by the use of a mouthwash with a chlorhexidine solution $0.2 \%$; besides this, the patient should be examined weekly for plaque control and evaluation of the healing process ${ }^{17}$.

The Mucoderm ${ }^{\circledR}$ collagen matrix has been increased in recent years, Puišys et al. 2017 described a technique for single aesthetic implant placement with thickening of soft tissue, where they use Mucoderm ${ }^{18}$. The collagen matrix demonstrated excellent aesthetic results, establishing and maintaining the bone wall and obtaining thick soft tissue ${ }^{19}$.

Pabst et al. (2016) in order to analyze the influence of Mucoderm ${ }^{\circledR}$ on endothelial progenitor cells (EPC) in vitro, have reported a good biocompatibility of this matrix, without any cytotoxic effects in EPC, thus promoting rapid revascularization and integration of soft tissues ${ }^{20}$.

Nocini et al. (2014) and Schmitt et al. (2016) concluded that the Mucoderm® collagen matrix may be a promising material as a substitute for autogenous connective tissue graft $^{21,22}$.

It is important to note that although Mucoderm ${ }^{\circledR}$ is a promising replacement for the autogenous graft, the literature does not have long-term follow-up clinical studies ${ }^{23,24}$. Therefore, further studies are needed to evaluate the biological behavior of the material. 


\section{Final considerations:-}

\section{It can be concluded from this study that:-}

The use of Mucoderm ${ }^{\circledR}$ in aesthetic area provides excellent results, establishing and maintaining the facial bone wall; in addition, contributes to the formation of a thick soft tissue in the aesthetic area, besides providing a better postoperative and avoiding a second surgical site.

\section{Conflicts of interest:-}

The authors declare that there are no conflicts of interest.

\section{References:-}

1. Vignoletti F, Nunez J, Sanz M. Soft tissue wound healing at teeth, dental implants and the edentulous ridge when using barrier membranes, growth and differentiation factors and soft tissue substitutes. J Clin Periodontol. 2014 Apr;41 Suppl 15:S23-35.

2. Dym H, Tagliareni JM. Surgical management of cosmetic mucogingival defects. Dent Clin North Am. 2012 Jan;56(1):267-79.

3. Grudianov AI, Zorina OA. [Use of TachoComb adhesive material after mucogingival operations]. Stomatologiia (Mosk). 2008;87(1):27-30.

4. Kahn S, Egreja AM, Barceleiro Mde O. Subepithelial connective tissue graft associated with apicoectomy and root-end fillings in the treatment of deep localized gingival recession with apex root exposure: case report. Int $\mathbf{J}$ Periodontics Restorative Dent. 2009 Aug;29(4):445-9.

5. Hirsch A, Goldstein M, Goultschin J, Boyan BD, Schwartz Z. A 2-year follow-up of root coverage using subpedicle acellular dermal matrix allografts and subepithelial connective tissue autografts. J Periodontol. 2005 Aug;76(8):1323-8.

6. Abbas F, Wennström J, Van der Weijden F, Schneiders T, Van der Velden U. Surgical treatment of gingival recessions using emdogain gel: clinical procedure and case reports. Int J Periodontics Restorative Dent. 2003 Dec;23(6):607-13.

7. Hürzeler MB, Weng D. Functional and esthetic outcome enhancement of periodontal surgery by application of plastic surgery principles. Int J Periodontics Restorative Dent. 1999 Feb;19(1):36-43.

8. Park JS, Pabst AM, Ackermann M, Moergel M, Jung J, Kasaj A. Biofunctionalization of porcine-derived collagen matrix using enamel matrix derivative and platelet-rich fibrin: influence on mature endothelial cell characteristics in vitro. Clin Oral Investig. 2018 Mar;22(2):909-917.

9. Kasaj A, Levin L, Stratul SI, Götz H, Schlee M, Rütters CB, Konerding MA, Ackermann M, Willershausen B, Pabst AM. The influence of various rehydration protocols on biomechanical properties of different acellular tissue matrices. Clin Oral Investig. 2016 Jul;20(6):1303-15.

10. Barbeck M, Lorenz J, Kubesch A, Böhm N, Booms P, Choukroun J, Sader R, Kirkpatrick CJ, Ghanaati S. Porcine Dermis-Derived Collagen Membranes Induce Implantation Bed Vascularization Via Multinucleated Giant Cells: A Physiological Reaction? J Oral Implantol. 2015 Dec;41(6):e238-51.

11. Pabst AM, Wagner W, Kasaj A, Gebhardt S, Ackermann M, Astolfo A, Marone F, Haberthür D, Enzmann F, Konerding MA. Synchrotron-based X-ray tomographic microscopy for visualization of three-dimensional collagen matrices. Clin Oral Investig. 2015 Mar;19(2):561-4.

12. Rothamel D, Benner M, Fienitz T, Happe A, Kreppel M, Nickenig HJ, Zöller JE. Biodegradation pattern and tissue integration of native and cross-linked porcine collagen soft tissue augmentation matrices - an experimental study in the rat. Head Face Med. 2014 Mar 27;10:10.

13. Zeng Y, Xiao L, Yao H, He J. [A study of the immune in formation of calcium bilirubinate gallstones in different rabbit models--the changes of the immunoglobulins in serum and bile and the immunoglobulins forming cells in the gallbladder mucoderm]. Hua Xi Yi Ke Da Xue Xue Bao. 2000 Jun;31(2):155-8.

14. Lima JFM, Matos JDM, Santos JPS, Oliveira AJAG, Vasconcelos JEL, Zogheib LV, Castro DS. Maxillary sinus lift surgery techniques: A literature review. Int. J. of Adv. Res. 2017; 5(8): 832-844.

15. Matos JDM, Santos IKS, Perreira ALC, Oliveira, AJAG, Vasconcelos BCG, Pita Neto IC. Vasconcelos JEL. The use of the rich fibrin in platelets and leukocytes as alternative treatment for lifting the maxillary sinus - A literature review. Int. J. of Dev. Res. 2017; 7(6): 13436-13441.

16. Pereira ALC, Matos JDM, Cavalcante-Pereira N, Franco JMPL, Vasconcelos BCG, Vardiero VA, Gomes TN, Vasconcelos, J. E. L. Maxillary Sinus lift and use of L-PRF with a delayed installation of implants-Case report. Int. J. of Dev. Res. 2017; 7(6): 13174-13177. 
17. Santos IKS, Matos JDM, Júnior CUFS, Oliveira AJAG, Franco JMPL, Vasconcelos BCG; Vasconcelos EMGM, Gomes TN, Vardiero VA, Vasconcelos JEL. Surgery of the maxillary sinus with piezocirurgic system use: Case report. Int J Inf Res Rev. 2017; 4(6): 4258-4260.

18. Puišys A, Žukauskas S, Kubilius R, Vindašiūte E, Linkevičius T. Bone augmentation and simultaneous soft tissue thickening with collagen tissue matrix derivate membrane in an aesthetic area. A case report. Stomatologija. 2017;19(2):64-68.

19. Pabst AM, Happe A, Callaway A, Ziebart T, Stratul SI, Ackermann M, Konerding MA, Willershausen B, Kasaj A. In vitro and in vivo characterization of porcine acellular dermal matrix for gingival augmentation procedures. J Periodontal Res. 2014 Jun;49(3):371-81.

20. Pabst AM, Lehmann KM, Walter C, Krüger M, Stratul SI, Kasaj A. Influence of porcine-derived collagen matrix on endothelial progenitor cells: an in vitro study. Odontology. 2016 Jan;104(1):19-26.

21. Nocini PF, Castellani R, Zanotti G, Gelpi F, Covani U, Marconcini S, de Santis D. Extensive keratinized tissue augmentation during implant rehabilitation after Le Fort I osteotomy: using a new porcine collagen membrane (Mucoderm). J Craniofac Surg. 2014 May;25(3):799-803.

22. Schmitt CM, Matta RE, Moest T, Humann J, Gammel L, Neukam FW, Schlegel KA. Soft tissue volume alterations after connective tissue grafting at teeth: the subepithelial autologous connective tissue graft versus a porcine collagen matrix - a pre-clinical volumetric analysis. J Clin Periodontol. 2016 Jul;43(7):609-17.

23. Sanz M, Lorenzo R, Aranda JJ, Martin C, Orsini M. Clinical evaluation of a new collagen matrix (Mucograft prototype) to enhance the width of keratinized tissue in patients with fixed prosthetic restorations: a randomized prospective clinical trial. J Clin Periodontol. 2009 Oct;36(10):868-76.

24. Proêza AP, Corteletti1 MM, Balbino1 HCG, Chiarelli FM, Matos JDM, Lopes GRS. Guided bone regeneration with biomaterial use and reaboresorvable membrane: A case report. Int. J. Adv. Res. 2018; 6(5), 884-890. 